\title{
Research on Growth Characteristics of Green-Tide-Forming Green Algae under Stress Conditions
}

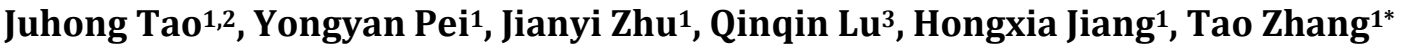 \\ ${ }^{1}$ Department of Biology, Changshu Institute of Technology, Changshu, China \\ ${ }^{2}$ Changshu Institute of Agriculture Science, Changshu, China \\ ${ }^{3}$ Jiangsu Institute of Oceanology and Marine Fisheries, Nantong, China \\ Email: ${ }^{\star}$ zhangtao@cslg.edu.cn
}

How to cite this paper: Tao, J.H., Pei, Y.Y., Zhu, J.Y., Lu, Q.Q., Jiang, H.X. and Zhang, T. (2021) Research on Growth Characteristics of Green-Tide-Forming Green Algae under Stress Conditions. Open Journal of Marine Science, 11, 157-168. https://doi.org/10.4236/ojms.2021.114010

Received: April 22, 2021

Accepted: September 4, 2021

Published: September 7, 2021

Copyright $\odot 2021$ by author(s) and Scientific Research Publishing Inc. This work is licensed under the Creative Commons Attribution International License (CC BY 4.0).

http://creativecommons.org/licenses/by/4.0/

\begin{abstract}
The cytological characteristics of major green-tide-forming green algae Ulva prolifera collected from Yellow Sea were studied through cutting segments, long time low temperature or dark treatments. After being dried in the shade and preserved at $-20^{\circ} \mathrm{C}$ for 30 days, the $U$. prolifera was cultured at $4{ }^{\circ} \mathrm{C}$ in sterilized seawater under $40 \mu \mathrm{mol}$ photons $\mathrm{m}^{-2} \cdot \mathrm{s}^{-1}$ light intensity for 120 days, results indicated that the plastid of $U$. prolifera continuously shrank with the extension of treatment, and most cells turned white and died, only a small amount of cells still contained a few of visible inclusions at the $120 \mathrm{~d}$ of treatment. Then those samples were transferred to $20^{\circ} \mathrm{C}$ and $40 \mu \mathrm{mol}$ photons $\mathrm{m}^{-2} \cdot \mathrm{s}^{-1}$ condition for recovery cultivation, after about 10 days, some recovery cells were observed in the thallus, and those cells developed to young thallus gradually and released germ cells almost in the same time. After about 60 days of recovery cultivation, the newly-grown green thallus broke through the original dead thallus, and the germ cells also grew to new individual thallus. Before dark treatment, the $U$. prolifera cells were filled with plastid, contained visible starch grain and discernible cell outlines, while after 120 days of dark treatment, the plastid shrank and degraded together with the disappearance of cell inclusions, and the cell outlines also blurred, then those samples were transferred to optimal culture conditions at $20^{\circ} \mathrm{C}$ in $40 \mu \mathrm{mol}$ photons $\mathrm{m}^{-2} \cdot \mathrm{s}^{-1}$ light intensity, and 15 days later, newly-grown cells appeared on the almost dead thallus, these cells divided continuously and grew to young thallus, and those newly-grown thallus also generated active germ cells, which developed to new thallus that cytologically identical to the original thallus. Observation of chopped tissue of $U$. prolifera cultivated at $20^{\circ} \mathrm{C}, 40 \mu \mathrm{mol} \mathrm{m}^{-2} \cdot \mathrm{s}^{-1}$ showed that the morphological upper part cells turned to germ cells first, those germ
\end{abstract}


cells including gametophyte and sporophyte, which released later and grew to new individual thallus. These findings provided cytological evidences for how $U$. prolifera live through stress conditions such as low temperature, darkness, and also useful for understanding the mechanism of the occurrence of green tide.

\section{Keywords}

Ulva prolifera, Green Tide, Cytology, Temperature, Stress

\section{Introduction}

The green tide is a natural disaster caused by the explosive growth of some green macroalga, in which Ulva is turned out to be the main species. There are varying degrees of green tide outbreaks at the Yellow Sea of China since 2007, especially the largest green tide occurred in Qingdao 2008. The green tide has negative effects on the sea ecological environment, such as competition for the nutrition and oxygen which broke the ecological balance of other seaweeds and animals, and also brought huge losses to coastal economy [1] [2] [3] [4]. Considering the impact of green tide on human society and economy, ecologists attach great importance to the study of the mechanism of green tide.

It is always a hot topic about the source of green tide. Many reports suggested that the green tide forming algae $U$. prolifera was originated from the South Yellow Sea [2] [5] [6], and believed there are seaweed mats in the Yellow Sea. Investors also observed micro propagule in Yellow Sea, and found co-relationship between the amount of micro propagule and the development of green tide [7]. While some reports proposed that the source of green tide may come from aquaculture ponds [3], or probably originated from the coastal areas of the southwest Yellow Sea [8], or from the somatic cells embedded in the sediment [9].

The outbreak of green tide is closely related to the environment, except the direct relationship with eutrophication [10], the rise of seawater temperature in spring is also a key factor for the floating of green algae [11]. Recent report indicates floating green algae occurred in Yellow Sea area when the seawater temperature rises to $12^{\circ} \mathrm{C}-15^{\circ} \mathrm{C}$ [12]. In addition, light intensity also plays an important role in green algae floating through affecting photosynthesis and oxygen evolution. The stress adaptation ability and special reproduction pattern of $U$. prolifera made it to be the dominant species in green tide. $U$. prolifera can grow fast by using the nutrition in seawater such as nitrogen, the highest daily growth rate can reach up to $50 \%$ under optimal conditions [13]. U. prolifera can adapt to dramatic changes in salinity, light intensity and dehydration [14] [15] [16] [17]. There are various reproductive patterns of $U$. prolifera, including sexual reproduction, asexual reproduction and vegetative proliferation [18]. The micro propagule and thalli of $U$. prolifera may survive under low temperature or dark conditions [9]. All those biological characteristics make $U$. prolifera the domi- 
nant species in the green tide.

Normally, the floating green macroalgae emerges around April, and then the biomass increased greatly with the rapid growth of macroalgae especially $U$. prolifera, and those algae began to degraded or sank into the sea around August. The seawater temperature of the Yellow Sea decreased gradually from August. Therefore, living through this low temperature period is crucial for the reoccurrence of green tide in the next year. Seaweed mats are considered to be the source of floating green algae, which may be consisted of overwintering adult plants [9], settled spores, or other microscopic forms of the life cycle that remain dormant or survive with little growth until environmental conditions become favorable [19] [20] [21], while little cytological research has done on the survival and regeneration of green macroalgae in dark and low temperature. In this study, we put the floating $U$. prolifera sample under low temperature, darkness for a long period and transferred it to optimal condition, cytological characteristics of sample were observed, in order to study how $U$. prolifera live through stress conditions and discuss the relationship with the occurrence of green tide.

\section{Materials and Methods}

\subsection{Collection and Culture of Ulva prolifera}

The thalli were collected at the Yellow Sea from May to July 2016 (see Table 1), and transported to the lab in a cool box $\left(4^{\circ} \mathrm{C}-6^{\circ} \mathrm{C}\right)$ within $4 \mathrm{~h}$ and then washed out gently with sterilized seawater. Healthy thalli vegetative tissues were selected for further experiment.

Low temperature treatment: $U$. prolifera sample first dried in the shade and preserved at $-20^{\circ} \mathrm{C}$ for 30 days, then put them in the triangular flasks with sterile seawater and cultured at $4^{\circ} \mathrm{C}, 40 \mu \mathrm{mol}$ photons $\mathrm{m}^{-2} \cdot \mathrm{s}^{-1}$ light conditions, and the sterile seawater was replaced every 2 days. Cytological observations of thalli were performed every 3 days.

Dark treatment: $U$. prolifera sample were suspended in triangular flasks with fresh sterile seawater at $4^{\circ} \mathrm{C}$ and placed in opaque boxes for culture. The sterile seawater was replaced every 2 days. Cytological observations of thalli were performed every 7 days.

Segments culture: the cytological upper part of healthy thallus were cut to $1-3$ $\mathrm{cm}$ in length and put in culture dishes with fresh sterile seawater. The sterile

Table 1. Overview of collection site and time of Ulva prolifera sample.

\begin{tabular}{ccc}
\hline No. & Collection time & Collection site \\
\hline Yancheng Floating algae & $2016-6-19$ & $33^{\circ} 48^{\prime} \mathrm{N} 121^{\circ} 20^{\prime} \mathrm{E}$ \\
Lianyugang Floating algae & $2016-6-24$ & $34^{\circ} 58^{\prime} \mathrm{N} 119^{\circ} 48^{\prime} \mathrm{E}$ \\
Qingdao Floating algae & $2016-7-24$ & $36^{\circ} 03^{\prime} \mathrm{N} 120^{\circ} 20^{\prime} \mathrm{E}$ \\
Dafeng Floating algae & $2016-5-23$ & $33^{\circ} 48^{\prime} \mathrm{N} 121^{\circ} 10^{\prime} \mathrm{E}$ \\
Rudong Floating algae & $2016-6-18$ & $36^{\circ} 03^{\prime} \mathrm{N} 120^{\circ} 22^{\prime} \mathrm{E}$ \\
\hline
\end{tabular}


seawater was replaced every 2 days. Cytological observations of thalli were performed every 2 days.

Renewing culture process: those thallus, after several days of low temperature or dark treatment, were transferred to $20^{\circ} \mathrm{C}, 40 \mu \mathrm{mol}$ photons $\mathrm{m}^{-2} \cdot \mathrm{s}^{-1}$ and $12 \mathrm{~L}: 12 \mathrm{D}$ photoperiod condition, and the sterile seawater was replaced every 2 days. Cytological observations of thalli were performed every 2 days.

\subsection{Cytology Observation}

Cytology observations of $U$. prolifera were conducted using a light microscope (Nikon 90i, Tokyo, Japan). Three triangular flasks with 3 - 5 strains of $U$. prolifera were selected at random from each treatment and cytological characteristics of sample were observed.

\section{Results}

\subsection{Cytology Characteristics of $U$. prolifera before and after Low Temperature Treatment}

Before $4^{\circ} \mathrm{C}$ treatment, the cells of $U$. prolifera collected from different time and sites preserved at $-20^{\circ} \mathrm{C}$ arranged closely, and the cells were quadrangular or polygonal, the sizes of cells were different, the plastid occupied most part of the cells, and the pyrenoids also visible (Figures 1(1)-1(10)). After 120 days of $4^{\circ} \mathrm{C}$ temperature treatment, the cells changed obviously, most of cells losed green

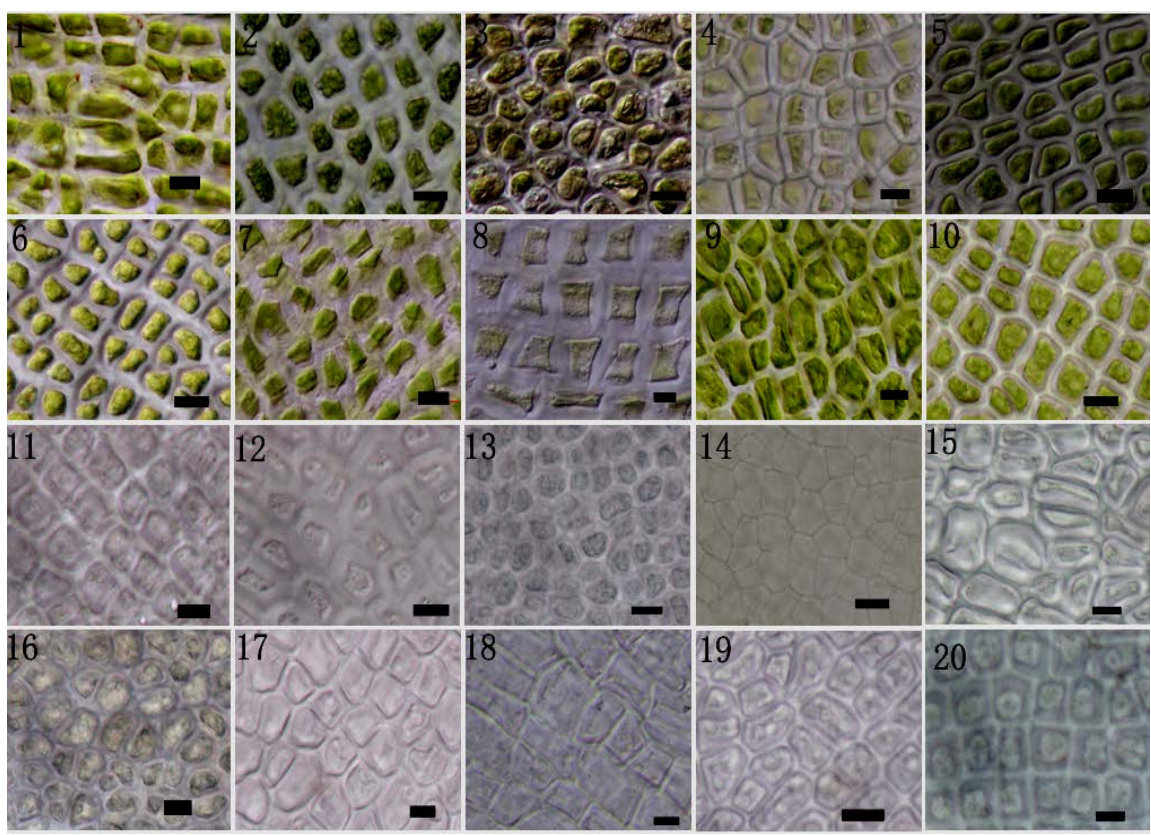

Figure 1. Cytological characteristics of $U$. prolifera before and after low-temperature treatment. (1-5): $U$. prolifera sample $\mathrm{YF}, \mathrm{LF}, \mathrm{QF}, \mathrm{DF}, \mathrm{RF}$ after preserved at $-20^{\circ} \mathrm{C}$ for 30 days; (6-10): repeats of $U$. prolifera sample $\mathrm{YF}, \mathrm{LF}, \mathrm{QF}, \mathrm{DF}, \mathrm{RF}$ after preserved at $-20^{\circ} \mathrm{C}$ for 30 days; (11-15): $U$. prolifera sample YF, LF, QF, DF, RF after 120 days of $4^{\circ} \mathrm{C}$ treatment; (16-20): repeats of $U$. prolifera sample YF, LF, QF, DF, RF after 120 days of $4^{\circ} \mathrm{C}$ treatment. Bar $=10 \mu \mathrm{m}$. 
and turned to white, the plastid degraded, the cell inclusions also disappeared and only cell walls were visible, and samples collected from different sites showed the same changes (Figures 1(11)-1(20)).

\subsection{Cytological Characteristics of $U$, prolifera before and after Dark Treatment}

Before dark treatment, the cells cultured at $4^{\circ} \mathrm{C}$ showed clear outline, and the plastid occupied most cells, and the vacuole and pyrenoids were visible (Figures 2(1)-2(5)); after 120 days of dark treatment, the shape of cell changed little, but the green color of cells lightened obviously, and the plastid shrunk and began to degrade, only occupied small part of cell (Figures 2(6)-2(10)); after 180 days of dark treatment, the cell inclusions almost disappeared and the cell outlines became indistinct under microscope (Figures 2(11)-2(15)).

\subsection{Cytological Characteristics of Renewing Cultured U. prolifera after Low Temperature Treatment}

The plastid and cells outlines were clearly observed at the 1 day of low temperature treatment (Figure 3(1)). After 45 days of low temperature treatment, most of the U. prolifera plastid degraded (Figure 3(2)). After 90 days of low temperature treatment, the plastid of sample almost disappeared (Figure 3(3), Figure $3(4))$.

After 10 days of renewing cultivation, recovery cells were observed in the original thallus (Figure 3(5)) and these cells divided continuously and formed clusters later, these cells also increased gradually in volume (Figure 3(6)). 40 days after renewing cultuvation, the recovery cells developed to a string of cells

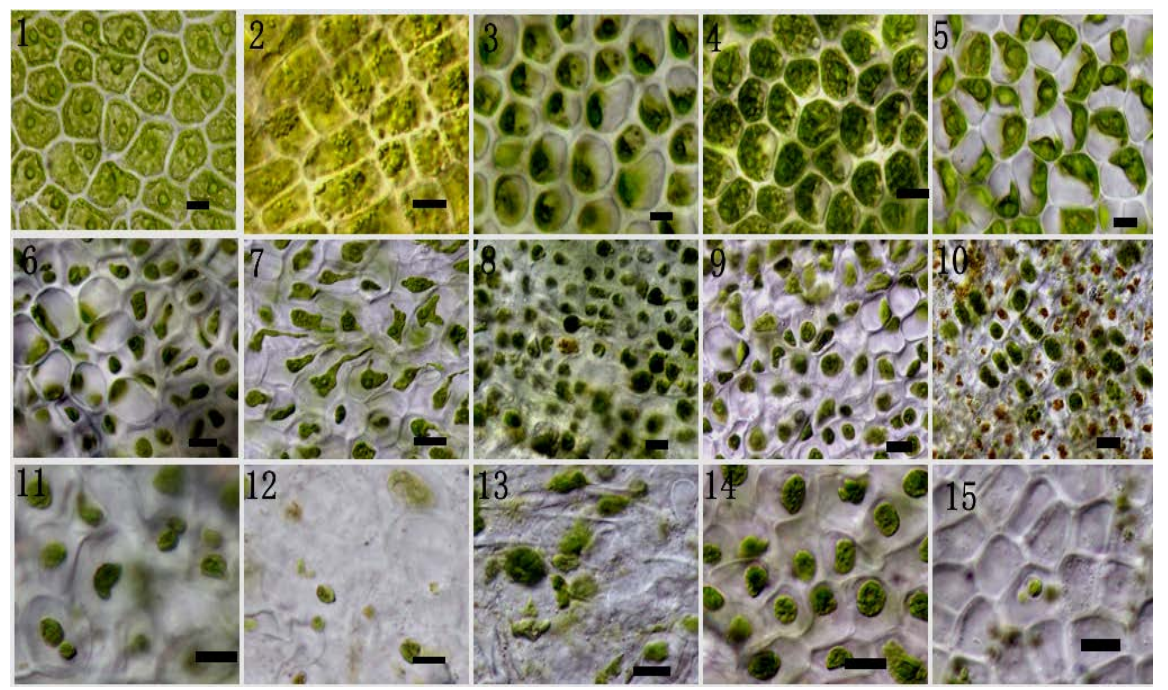

Figure 2. Cytological characteristics of $U$. prolifera before and after dark treatment. (1-5): characteristics of $U$. prolifera YF, LF, QF, DF, RF cells before dark treatment; (6-10): characteristics of $U$. prolifera $\mathrm{YF}, \mathrm{LF}, \mathrm{QF}, \mathrm{DF}, \mathrm{RF}$ cells after 120 days of dark treatment; (11-15): characteristics of $U$. prolifera YF, LF, QF, DF, RF cells after 180 days of dark treatment. Bar $=10 \mu \mathrm{m}$. 

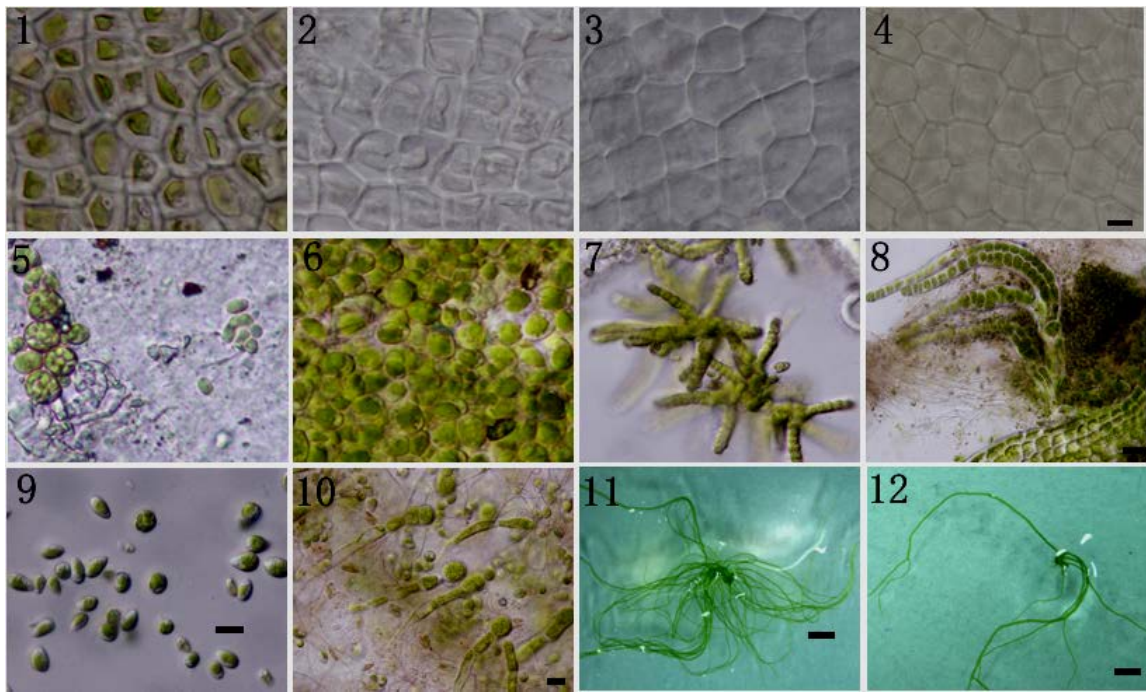

12

Figure 3. Cytological characteristics of $U$. prolifera under low temperature treatment and renewing culture. (1) Cells of $U$. prolifera after one-day low temperature treatment; (2) the plastid degraded after 45 days of low temperature treatment; (3) the plastid disappeared after 90 days of low temperature treatment; (4) cell inclusions disappeared after 120 days of low temperature treatment; (5) recovery cells were observed after 10 days of renewing culture; (6) the recovery cells divided rapidly and formed clusters after 40 days of renewing culture; (7) the recovery cells divided continuously to be multiple cells after 50 days of renewing culture; (8) the cell strings extended apart from the old thallus after 60 days of renewing culture; (9) germ cells were released around the thallus; (10) germ cells germinated; (11) young thallus grew from the original thallus after 65 day of renewing culture; (12) young thallus grew from the bottom of the culture dishes. Bar $=10 \mu \mathrm{m}$ in (1-10), Bar $=200 \mu \mathrm{m}$ in 11 and 12 .

(Figure 3(6)). 60 days later, these multiple cells strings continued to grow and extended apart from the original thallus (Figure 3(8)). During this process, a large number of germ cells were observed around the original thallus (Figure $3(9)$ ). The germ cells continue divided and grew to new individuals attaching on the bottom of the culture dishes or on the original thallus (Figure 3(10), Figure $3(11))$.

\subsection{Cytological Characteristics of Renewing Cultured $U$. prolifera after Dark Treatment}

Most cells were dead after a long period of dark treatment (Figure 4(1)). After 15 days of renewing culture, the recovery cells were observed on the dead thallus (Figure 4(2)). After 30 days of renewing culture, these cells gradually grew to clusters (Figure 4(3)) which continued to grow. After 35 days of renewing culture, the newly-grown thallus developed from the dead thallus (Figure 4(4)). Certain amounts of germ cells were generated around the thallus (Figure 4(5)), which grew to be new thallus later. After 45-days of recovery culture, a large number of new thallus were developed both from the dead thallus and the germ cells, which were cytologically identical to the original thalli (Figure 4(11), Figure 4(12)). 


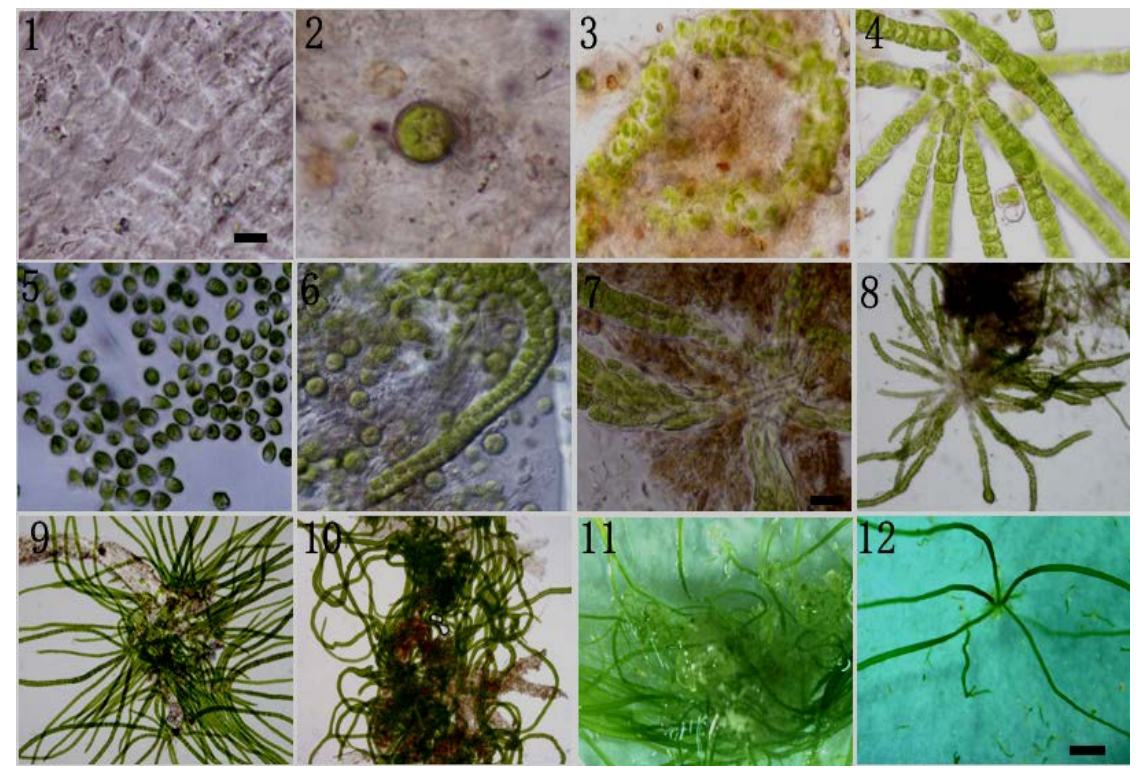

Figure 4. Cytological characteristics of renewing culture $U$. prolifera after dark treatment. (1) Cells of $U$. prolifera after 180 days of dark treatment; (2) the recovery cells were observed after 30 days of renewing culture; (3) the recovery cells divided to cell clusters after 40 days of renewing culture; (4) the recovery cells divided continuously to be multiple cells after 50 days of renewing culture; (5) germ cells were released around the thallus; (6-7) germ cells were germinated; (8) young thallus grew from the original thallus; (9-10) new thallus kept growing; (11) new young thallus grew on the original thallus; (12) new young thallus attached on the bottom of culture plat. Bar $=10 \mu \mathrm{m}$ in (1-7); Bar $=200 \mu \mathrm{m}$ in $(8-12)$.

\subsection{Development of Chopped U. prolifera Tissue}

In the process of chopped tissue cultivation, the cytological upper part of the thallus generated germ cells first. The color of the chopped tissue changed from green to yellow during the development of germ cells, and the cell arrangement became irregular (Figures 5(2)-5(4)). After about 2 - 3 days culture, the germ cells became mature, and moved rapidly within the sporangium, soon the germ cells diffused continuously though the hole, and finally left empty sporangium (Figure 5(7)). There were two kinds of germ cells, gametophyte and sporophyte, and the only differece is gametophyte had two flagellum while the sporophyte has four (Figure 5(7)). The germ cells were quite active when just released from the sporangium, after about $0.5 \mathrm{~h}$, they attached to suitable matrix and began to germinate (Figure 5(8), Figure 5(9)). These attached germ cells started to develop transparent protuberances after 3 days culture (Figure 5(10)). 5 days later, the basal cells divided and elongated to be rhizoid (Figure 5(11)). 7 days later, the apical cells started to divide (Figure 5(12)). The fascicled thallus divided both longitudinally and transversely (Figures 5(13)-5(15)), and developed new thallus attached on the bottom of the culture plat (Figure 5(16)).

\section{Discussion}

The green tide of Yellow Sea occured periodically, and the green algae started to 


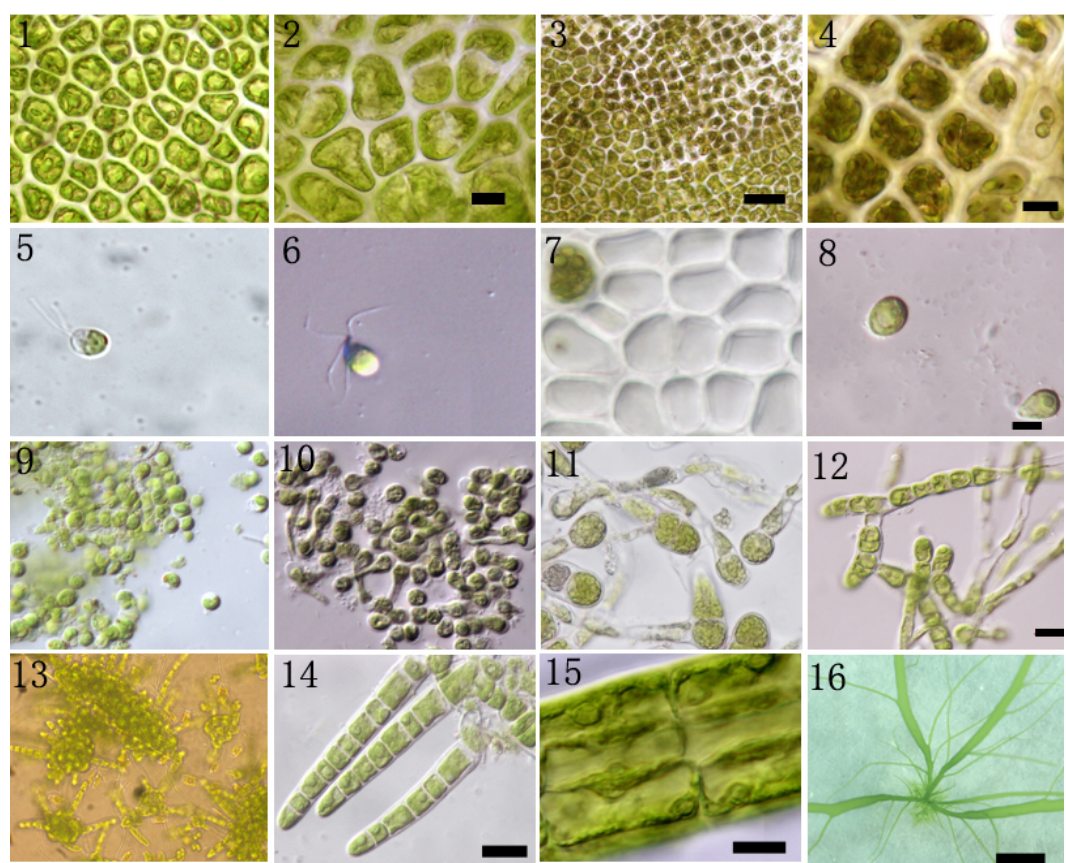

Figure 5. The development of $U$. prolifera cells after chop treatment. (1) Vegetative cells; (2) formation of gonocyte; $(3,4)$ formation of germ cells; (5) gametophyte; (6) sporophyte; (7) the empty sporangium; (8-9) attachment of germ cells; (10) germination of germ cells; (11-12) development of grem cells; $(13)$ formation of new thallus; $(14,15)$ division of cells; (16) new thallus attached on the bottom of culture plat. Bar $=10 \mu \mathrm{m}$ in $(1$, $2,4,9,10,11,12,13,14,15)$; $\operatorname{Bar}=5 \mu \mathrm{m}$ in $(5,6,7,8)$; Bar $=200 \mu \mathrm{m}$ in $(16)$.

float in about April every year, then grow and expand to large scale, finally degrade or sink into the sea in August [13] [22]. Therefore, the green algae live though the low temperature of the autumn and winter in un-floating state and explode again in next spring. It is generally acknowledged that the existence of "algae library", produced from settled spores, some microscopic organisms of life cycle and other vegetative fragments maintaining dormant or surviving with little growth, ensures the green tide periodically occurs under favorable environmental conditions [19] [20] [21].

$U$. prolifera has a variety of reproductive pattern [18], observation of the micro propagules of $U$. prolifera in Yellow Sea indicated that quantite changed periodically, and showed close relationship with the forming of floating green algae [23]. The micro propagules of $U$. prolifera perennially appeared in sea area of the north of Jiangsu province [24] [25] [26], while it only presented with the floating of green algae in sea area of Qingdao and almost disappeared in the end of green tide in August [23] [27] considered that the rocks along the Qingdao coast were more difficulty for $U$. prolifera to attach and grow compared with the seaweed cultivation equipment from the south Yellow Sea. In addition, the surface seawater temperature of Qingdao sea area in winter can reach as low as $2^{\circ} \mathrm{C}$, which is believed unfavorable for the growth of $U$. prolifera [5].

The south Yellow Sea, where many researchers believed to be the source of green tide, is located in the entrance of the Yangtze River, the water of which 
brings adequate nutrition. Meanwhile, it forms unique geographical features with little rocks along the shore, turbid seawater and low light transmittance, where light is almost impossible to be detected under the surface of $1 \mathrm{~m}$. The germination and growth of micro propagules or somatic cells of $U$. prolifera depend on the environmental conditions such as temperature and light [21] [28]. Our results also indicated that the thallus cells under stress conditions, such as low temperature, darkness or chopping, can restore growth very well in $20^{\circ} \mathrm{C}$ under $40 \mu \mathrm{mol}$ photons $\mathrm{m}^{-2} \cdot \mathrm{s}^{-1}$ light intensity. Under natural conditions in spring, the lighting conditions of the south Yellow Sea may be the limiting factor for the germination of micro propagules and no large-scale green tide had been reported in this sea area. Thus how do micro propagules of $U$. prolifera in the south Yellow Sea grow in spring still need further study.

It had been reported that there are different ways about how $U$. prolifera overwinters the unfavorable environment, including propagules and somatic cells forms [9] [20] [21]. Schories (1995) proposed that the contribution of asexual spores to the growth of Ulva in spring was negligible, but the real "source" was those mature algae which mixed with sediments and passed the low temperature stage of winter, Zhang et al. (2010) also supported this option. Our results also showed that the mature thallus cells almost dead after a long period of low temperature or darkness, but some cells recovered growth several days after transferred to optimal conditions, those cells grew to young thallus finally. While the difference with the above reports was that a large number of germ cells, including gametophyte and sporophyte, were developed and released from the recoveried cells. These germ cells were able to germinate and grow rapidly. So we propose that both the surviving cells and the germ cells may be the "seed" source for the regrowth of floating $U$. prolifera at optimal conditions after long time of low temperature and darkness.

\section{Conclusions}

1) Cultured at $4^{\circ} \mathrm{C}$ and $40 \mu \mathrm{mol}$ photons $\mathrm{m}^{-2} \cdot \mathrm{s}^{-1}$ light intensity for 120 days, most cells of $U$. prolifera turned white and died; after being transferred to $20^{\circ} \mathrm{C}$ and $40 \mu \mathrm{mol}$ photons $\mathrm{m}^{-2} \cdot \mathrm{s}^{-1}$, some recovery cells were observed in the thallus after about 10 days, and those cells developed to young thallus gradually and released germ cells almost in the same time. After about 60 days of recovery cultivation, the newly-grown green thallus broke through the original dead thallus, and the germ cells also grew to new individual thallus.

2) After 120 days of dark treatment, the plastid of $U$. prolifera shrank and degraded; after being transferred to optimal culture conditions at $20^{\circ} \mathrm{C}$ in $40 \mu \mathrm{mol}$ photons $\mathrm{m}^{-2} \cdot \mathrm{s}^{-1}$ light intensity for 15 days, newly-grown cells appeared on the almost dead thallus, these cells divided continuously and grew to young thallus, and those newly-grown thallus also generated active germ cells.

3) Chopped tissue of $U$. prolifera cultivated at $20^{\circ} \mathrm{C}, 40 \mu \mathrm{mol} \cdot \mathrm{m}^{-2} \cdot \mathrm{s}^{-1}$ showed that the morphological upper part cells turned to germ cells first, those germ 
cells including gametophyte and sporophyte, which released later and grew to new individual thallus.

These findings provided cytological evidences for how $U$. prolifera live through stress conditions such as low temperature, darkness, and also useful for understanding the mechanism of the occurrence of green tide.

\section{Acknowledgements}

National Marine Public Welfare Profession Scientific Research Special (2012418026); Modern Agriculture Industrial Research System of Jiangsu Province (JATS[2020]464).

\section{Conflicts of Interest}

The authors declare no conflicts of interest regarding the publication of this paper.

\section{References}

[1] Lin, A., Wang, C., Qiao, H., Pan, G., Wang, G., Song, L., Wang, Z., Sun, S. and Zhou, B. (2009) Study on the Photosynthetic Performances of Enteromorpha prolifera Collected from the Surface and Bottom of the Sea of Qingdao Sea Area. Chinese Science Bulletin, 54, 399-404. https://doi.org/10.1007/s11434-009-0025-6

[2] Liu, D., Keesing, J.K., Xing, Q. and Shi, P. (2009) World's Largest Macroalgal Bloom caused by Expansion of Seaweed Aquaculture in China. Marine Pollution Bulletin, 58, 888-895. https://doi.org/10.1016/j.marpolbul.2009.01.013

[3] Pang, S., Liu, F., Shan, T., Xu, N., Zhang, Z., Gao, S., Chopin, T. and Sun, S. (2010) Tracking the Algal Origin of the Ulva Bloom in the Yellow Sea by a Combination of Molecular, Morphological and Physiological Analyses. Marine Environmental Research, 69, 207-215. https://doi.org/10.1016/j.marenvres.2009.10.007

[4] Van Alstyne, K.L., Nelson, T.A. and Ridgway, R.L. (2015) Environmental Chemistry and Chemical Ecology of "Green Tide" Seaweed Blooms. Integrative and Comparative Biology, 55, 518-532. https://doi.org/10.1093/icb/icv035

[5] Liu, D., Keesing, J., Dong, Z., Zhen, Y., Di, B., Shi, Y., Fearns, P. and Shi, P. (2010) Recurrence of the World's Largest Green-Tide in 2009 in Yellow Sea, China: Porphyra yezoensis Aquaculture Rafts Confirmed as Nursery for Macroalgal Blooms. Marine Pollution Bulletin, 60, 1423-1432. https://doi.org/10.1016/j.marpolbul.2010.05.015

[6] Zhang, J.H., Zhao, P., Huo, Y.Z., Yu, K.F. and He, P.M. (2017) The Fast Expansion of Pyropia Aquaculture in "Sansha" Regions Should Be Mainly Responsible for the Ulva Blooms in Yellow Sea. Estuarine, Coastal and Shelf Science, 189, 58-65. https://doi.org/10.1016/j.ecss.2017.03.011

[7] Huo, Y., Hua, L., Wu, H., Zhang, J.H., Cui, J., Huang, X., Yu, K.F., Shi, H., He, P.M. and Ding, D.W. (2014) Abundance and Distribution of Ulva Microscopic Propagules Associated with a Green Tide in the Southern Coast of the Yellow Sea. Harmful Algae, 39, 357-364. https://doi.org/10.1016/j.hal.2014.09.008

[8] Ding, L., Fei, X., Lu, Q.Q., Deng, Y.Y. and Lian, S. (2009) The Possibility Analysis of Habitats, Origin and Reappearance of Bloom Green Alga (Enteromorpha prolifera) on Inshore of Western Yellow Sea. Chinese Journal of Oceanology and Limnology, 27, 421-424. https://doi.org/10.1007/s00343-009-9277-x 
[9] Zhang, X., Wang, H., Mao, Y., Liang, C., Zhuang, Z.M., Wang, Q. and Ye, N.H. (2010) Somatic Cells Serve as a Potential Propagule Bank of Enteromorpha prolifera Forming a Green Tide in the Yellow Sea, China. Journal of Applied Phycology, 22, 173-180. https://doi.org/10.1007/s10811-009-9437-6

[10] Pedersen, M.F. and Borum, J. (1997) Nutrient Control of Estuarine Macroalgae: Growth Strategy and the Balance between Nitrogen Requirements and Uptake. Marine Ecology Progress Series, 161, 155-163. https://doi.org/10.3354/meps161155

[11] Lobban, C.S., Harrison, P.J. and Duncan, M.J. (1985) The Physiological Ecology of Seaweeds. Biologia Plantarum, 28, 140. https://doi.org/10.1007/BF02885213

[12] Fan, S., Fu, M., Yan, L., Wang, Z., Fang, S., Jiang, M., Wang, H., Sun, P. and Qu, P. (2012) Origin and Development of Huanghai (Yellow) Sea Green-Tides in 2009 and 2010. Acta Oceanologica Sinica, 34, 187-194.

[13] Zhang, J.H., Huo, Y.Z., Yu, K.F., Chen, Q., He, Q., Han, W., Chen, L., Cao, J., Shi, D. and He, P.M. (2013) Growth Characteristics and Reproductive Capability of Green Tide Algae in Rudong Coast, China. Journal of Applied Phycology, 25, 795-803. https://doi.org/10.1007/s10811-012-9972-4

[14] Wang, G.C., Pan, G.H., Lin, A.P. and Peng, G. (2010) A Strategy for the Proliferation of Ulva prolifera, Main Causative Species of Green Tides, with Formation of Sporangia by Fragmentation. PLoS ONE, 5, e8571. https://doi.org/10.1371/journal.pone.0008571

[15] Gao, S., Shen, S.D., Wang, G.C., Niu, J.F., Lin, A.P. and Pan, G.H. (2011) PSI Driven Cyclic Electron Flow Allows Intertidal Macro-Algae Ulva sp. (Chlorophyta) to Survive in Desiccated Conditions. Plant and Cell Physiology, 52, 885-893. https://doi.org/10.1093/pcp/pcr038

[16] Gao, S., Zheng, Z., Gu, W., Xie, X., Huan, L., Pan, G. and Wang, G.C. (2014) Photosystem I Shows a Higher Tolerance to Sorbitol-Induced Osmotic Stress than Photosystem II in the Intertidal Macro-Algae Ulva prolifera (Chlorophyta). Physiologia Plantarum, 152, 380-388. https://doi.org/10.1111/ppl.12188

[17] Luo, M., Liu, F. and Xu, Z. (2012) Growth and Nutrient Uptake Capacity of Two Co-Occurring Species, Ulva prolifera and Ulva linza. Aquatic Botany, 100, 18-24. https://doi.org/10.1016/j.aquabot.2012.03.006

[18] Lin, A.P., Shen, S.D., Wang, J. and Yan, B. (2008) Reproduction Diversity of Enteromorpha prolifera. Journal of Integrative Plant Biology, 50, 622-629. https://doi.org/10.1111/j.1744-7909.2008.00647.x

[19] Santelices, B. (1990) Patterns of Reproduction, Dispersal and Recruitment in Seaweeds. Oceanography and Marine Biology, 28, 177-276.

[20] Hoffmann, A.J. and Santelices, B. (1991) Banks of Algal Microscopic Forms: Hypotheses on Their Functioning and Comparisons with Seed Banks. Marine Ecology Progress Series, 79, 185-194. https://doi.org/10.3354/meps079185

[21] Worm, B., Heike, K. and Sommer, U. (2001) Algal Propagules Banks Modify Competition, Consumer and Resource Control on Baltic Rocky Shores. Oecologia, 128, 281-293. https://doi.org/10.1007/s004420100648

[22] Han, W., Chen, L.P., Zhang, J.H., Tian, X.L., Liang, H., He, Q., Huo, Y.Z., Yu, K.F., Shi, D., Ma, J.H. and He, P.M. (2013) Seasonal Variation of Dominant Free-Floating and Attached Ulva Species in Rudong Coastal Area, China. Harmful Algae, 28, 46-54. https://doi.org/10.1016/j.hal.2013.05.018

[23] Miao, X.X., Xiao, J., Pang, M., Zhang, X., Wang, Z.L., Miao, J. and Li, Y. (2018) Effect of the Large-Scale Green Tide on the Species Succession of Green Macroalgal Micro-Propagules in the Coastal Waters of Qingdao, China. Marine Pollution Bul- 
letin, 126, 549-556. https://doi.org/10.1016/j.marpolbul.2017.09.060

[24] Li, Y., Song, W., Xiao, J., Wang, Z., Fu, M., Zhu, M., Li, R., Zhang, X. and Wang, X. (2014) Tempo-Spatial Distribution and Species Diversity of Green Algae MicroPropagules in the Yellow Sea during the Large-Scale Green Tide Development. Harmful Algae, 39, 40-47. https://doi.org/10.1016/j.hal.2014.05.013

[25] Song, W., Peng, K., Xiao, J., Li, Y., Wang, Z., Liu, X., Fu, M., Fan, S., Zhu, M. and Li, R. (2015) Effects of Temperature on the Germination of Green Algae Micro-Propagules in Coastal Waters of the Subei Shoal, China. Estuarine, Coastal and Shelf Science, 163, 63-68. https://doi.org/10.1016/j.ecss.2014.08.007

[26] Huo, Y., Han, H., Hua, L., Wei, Z., Yu, K., Shi, H., Kim, J.K., Yarish, C. and He, P.M. (2016) Tracing the Origin of Green Macroalgal Blooms Based on the Large Scale Spatio-Temporal Distribution of Ulva Microscopic Propagules and Settled Mature Ulva Vegetative Thalli in Coastal Regions of the Yellow Sea, China. Harmful Algae, 59, 91-99. https://doi.org/10.1016/j.hal.2016.09.005

[27] Geng, H., Yan, T., Zhou, M. and Liu, Q. (2015) Comparative Study of the Germination of Ulva prolifera Gametes on Various Substrata. Estuarine, Coastal and Shelf Science, 163, 89-95. https://doi.org/10.1016/j.ecss.2014.12.026

[28] Schories, D. (1995) Sporulation of Enteromorpha spp. (Chlorophyta) and Overwintering of Spores in Sediments of the Wadden Sea, Island of Sylt, North Sea. Netherlands Journal of Aquatic Ecology, 29, 341-347. https://doi.org/10.1007/BF02084233 